\title{
Mali Bakış Açısı ile Çevresel Kirliliklerin Azaltılmasında Elektrikli Taşıtların Rolü
}

\author{
Mehmet Emin Kenanoğlua, b, Timur Türgayc
}

\section{Özet}

Sınırlı rezerv miktarına sahip fosil yakıt kaynakları çevresel kirlenmelerin artmasında önemli rol oynamaktadır. Fosil yakıtların ulaşım sisteminde yüksek düzeyde kullanılması ile ortaya çıkan etkileri de tüm yaşam formlarını olumsuz yönde etkilemektedir. Küreselleşme olgusu ise bu etkilerin tüm yerkürede hissedilmesi sonucunu doğurmaktadır. Küresel kirlenmeye neden olan bu olgu teknolojik gelişmelerde meydana gelen dönüşüm dalgasıyla, elektrikli taşıtların yeniden ortaya çıkmasına olanak sağlamış ve çevresel kirliliklerin giderilmesinde bir çözüm önerisi olarak ön plana çıkmıştır. Elektrikli taşıtlar özellikle yakıt tüketimi konularında avantaj sağlayarak gürültü, görüntü ve hava kirliliği gibi çevre kirliliklerinden kaynaklanan birçok olumsuzluğu lehe dönüştürmektedir. Çalışmada, literatür taraması ekseninde, çevresel kirlilikleri azaltma rolü üstlenebilecek elektrikli taşıtlar mali perspektiften tartışılmıştır.
Anahtar Kelimeler

Küresel Kamusal Mallar

Çevresel Kirlilikler

Elektrikli Taşıtlar

Makale Hakkında

Geliş Tarihi: 15.03.2019

Kabul Tarihi: 24.04 .2020

Doi: 10.18026/cbayarsos.540547

\section{The Role of Electrical Vehicles in Decreasing Environmental Pollution with Public Finance Perspective}

\begin{abstract}
Fossil fuel resources with a limited reserve play an important role in increasing environmental pollution. The high-level usage of fossil fuels in transportation system and the resulting effects negatively affect all living creatures. The globalization phenomenon causes these effects to be felt all over the entire globe. This phenomenon, which causes global pollution, has led to the reemergence of electric vehicles are with a massive wave of transformation in technological developments and has come to the fore as a solution for the removal of environmental pollution. Electric vehicles are particularly advantageous in fuel consumption and have preventive effects over most of the problems caused by environmental pollution such as noise, image and air pollution. In this context in addition to the literature review, the study discusses the effects of electric vehicles that will reduce pollution at the global level.
\end{abstract}

\author{
Keywords \\ Global Public Goods \\ Environmental Pollution \\ Electrical Vehicles \\ About Article \\ Received: 15.03.2019 \\ Accepted: 24.04.2020
}

Doi: 10.18026/cbayarsos.540547

a İletişim Yazarı: mehmeteminkenanoglu@comu.edu.tr

b Arş. Gör., Çanakkale Onsekiz Mart Üniversitesi, İktisadi ve İdari Bilimler Fakültesi, Maliye Bölümü, ORCID numarası: 0000-0003-1044-6674

c Doç. Dr., Çanakkale Onsekiz Mart Üniversitesi, İktisadi ve İdari Bilimler Fakültesi, Maliye Bölümü, ORCID numarası. 0000-0002-3283-8153 


\section{Giriş}

Küreselleşme olgusu ile dünyanın farklı noktalarında yaşanan gelişmeler artık çok hızlı şekilde yayılmakta ve bu durum her yönüyle (ürünler, insanlar, fikirler, görüntüler, kirlilik vs.) birbirine bağlı bir dünya yaratmaktadır. İşte bu noktada bir yandan küreselleşmenin nimetlerinden faydalanırken diğer bir yandan da ortaya çıkan çevresel kirlilik gibi olumsuzluklara maruz kalınmaktadır. Bu panorama içerisinde ortaya çıan kirliliklerin bertaraf edilmesi noktasında kurumlara düşen birçok görev bulunmaktadır. Ancak beklenti ve çıkarların farklılığı gibi durumlarda tüm ulusların konuya aynı hassasiyeti göstereceği veya aynı beceri düzeyine ulaşabilecekleri şüphelidir. Bu nedenle teknolojik kökenli çevresel kirliliklerin azaltılmasında elektrikli taşıtlar, gelişme trendine uyumlu ve uygun bir çözüm önerisi olarak sayılabilir. Nitekim ortaya çıkan hava ve çevre kirliliğinin önemli sebeplerinden biri teknolojik gelişme trendine aykırı fosil yakıt kullanımıdır. Bu çerçevede fosil yakıt kullanımı gerçekleştiren eski teknoloji taşıtlar da önemli bir bileşen durumundadır. Elektrikli taşıtların çevresel kirliliklere çözüm olarak sunulmasındaki amaç; bu taşıtların fosil yakıt kullanan eski teknoloji taşıtların yerini alması durumunda tüm dünya üzerinde kullanılacağı ve çevre kirliliği üzerine olumlu etkilerinin kısa sürede sonuç vererek fosil yakıt kullanımını önemli düzeyde azaltma potansiyeline sahip olmasıdır. Nitekim sadece hava kirliliğinin Avrupa Birliği (AB) bütçesine yıllık maliyeti ortalama 80 milyar Avrupa Birliği avro (EUR)'suna dayandığ 1 dikkate alındığında bu önemli bir sonuçtur. Bu çerçeve yönüyle çalışmada, literatür taraması ekseninde, küresel kamusal mal olarak çevre ve çevresel kirlilikler, elektrikli taşıtlar ve ortaya çıkardığı etkileri mali perspektiften ele alınarak tartışılmıştır.

\section{Küreselleşme, Küresel Kamusal Mallar ve Özellikleri}

Küreselleşme, dünyanın belli başlı bölgeleri ve çok çeşitli etkinlik alanları (ekonomik, siyasal, sosyal ve kültürel vs.) arasındaki bağlardan oluşmaktadır. 20. yüzyılın sonlarında üretilen bu "büyük fikir", 1980'li yıllarda yoğun bir şekilde gündeme gelmeye başlamış olsa da arka planında 1970'li yıllarda meydana gelen birtakım gelişmeler bulunmaktadır. Bu gelişmeler; gelişmiş kapitalist ülkelerin (Amerika Birleşik Devletleri (ABD) ve İngiltere) iç piyasalarının yeterli doygunluğa ulaşması sonucu kâr hadlerinin azalması ve bu durumun getirdiği dış piyasalara açılma ihtiyacı, Sovyetler Birliği'nin dağılmasıyla dünyanın ideolojik bakımdan tek kutuplu hale gelmesi ve artan teknolojik gelişmeler olarak ifade edilmektedir. Bu süreçte birbirine entegre olmuş teknolojik gelişmeler neticesinde, dünyanın farklı noktalarında yaşanan gelişmelerden çok hızlı şekilde haberdar olunabilmesi ile sosyal etkileşimler de artmıştır (Held vd., 2015: 71; Yusufoğlu ve Özpençe, 2015: 16; Kazgan, 2016: 21).

Küreselleşme, geleneksel ve klasik aktivitelerin sınır ötesi hale gelmesine olanak tanımıştır. $\mathrm{Bu}$ sayede ürünler, insanlar, fikirler, görüntüler, kirlilik ve müzik gibi olguların sınırları aşması kolaylaşmıştır. Ekonomik, sosyal ve siyasal birçok engelin azalması veya tamamen ortadan kalkmasıyla üretim faktörlerinin serbest dolaşımı kolaylaşmıştır. Böylece küreselleşme ülkeleri yalnızca ekonomik yapı bakımından değil sosyal, siyasi ve mali yapıları bakımından da etkiler hale gelmiştir. 2003 yılı ilkbaharında Şiddetli Akut Solunum Sistemi Sendromu ya da kamuoyunda bilinen adıyla SARS salgını, küreselleşmenin yerel politika kaygılarının nasıl aniden uluslararası düzeyde bir konu haline gelebildiğinin çarpıcı bir örneği olmuştur. Bu salgın, Çin Halk Cumhuriyeti'nin Güney'inde bulunan hastalıklı 
hayvanlardan hızla diğer ülkelere yayılmıştır. İlkbaharın sonunda Toronto'da 39 kişi ölmüş ve 27 bin kişi karantinaya alınmıştır (Aytaç, 2018: 133; Matsui ve Morduch, 2003: 2).

Küresel kamusal mallar; ülkeler, insanlar ve nesiller (bugünkü ve gelecekteki) açısından faydası önemli ölçüde evrensel olan mallar olarak ifade edilmektedir. Bu yönüyle küresel kamusal mallar akademik düzeyde en aktif araştırma konularından biri olmuş ve küresel kamusal mal kavramı oldukça ilgi çekici hale gelmiştir (Kaul vd., 2003: 23; MFA ve MEFI 2002: 12; Altinay, 2013: 2). Bu kavram tanımlanırken bireyden ziyade toplumun tamamını ilgilendiren ihtiyaçlar ifade edildiğinden kamu kavramı dikkat çekmektedir. Bir malın küresel kamu malı olarak ifade edilmesi için öncelikle söz konusu malın etki düzeyi ve kapsadığ1 coğrafik alana bakmak gerekmektedir. Nitekim küresel kamusal mallar, birçok sosyo- ekonomik grup, ülke ve toplumun hem bugünkü hem de gelecekteki nesillerini etkileyebilmektedir (Yılmaz, 2010: 139). Kamusal malların esas olarak üç temel özellik çerçevesinde şekillendiği görülmektedir. Bu özellikler; dışsallıkların varlığı, ortaya çıkan faydadan dışlanamama ve tüketimde rekabetin olmamasıdır. Söz konusu özelliklerin ulusal sınırları aşması malın uluslararası bir hale gelmesi anlamına gelmektedir (Yusufoğlu ve Özpençe, 2015: 17).

Kamusal mallara ilişkin teoride yer alan güncel konulardan biri olan küresel kamusal mallar birçok farklı şekilde tanımlanmaktadır. Esas olarak tüketiminde rekabetin olmadığı ve dışlamanın mümkün olmadığı birtakım kamusal malların faydasının tüm dünyaya yayılması söz konusudur (Savaşan, 2017: 212). Aslında burada yayılan çıktı çoğu zaman fayda yerine zarar şeklindedir. Bu yönüyle küresel kamusal malların daha çok küresel manada zararlar şeklinde ortaya çıktığı ifade edilmektedir. Nitekim uluslararası çapta meydana gelen terör olayları, çölleşmenim artması, mali açıdan kötüleşen piyasalar, salgınlar, küresel ısınma tehdidinin artması, asit yağmurları, iş gücü standartlarının giderek kötüleşmesi gibi birçok olumsuzluk bu duruma örnek olarak verilmektedir. Küresel kamusal malları aşağıdaki gibi sınıflandırmak mümkündür (Yılmaz, 2010: 139-140);

a. Tam küresel kamu malları, tüketimde rekabetin olmaması ve hiç kimsenin dışarıda bırakılamadığı küresel düzeydeki mallar bu sinıflandırmaya girmektedir. Bu tür mallara okyanuslar ve atmosferin verilmesi mümkündür.

b. Yarı küresel kamu malları, bu tür malların tüketiminde rekabet ve dışarıda bırakma özellikleri noktasında kısmi bir durum söz konusudur. Bu tür mallara organize suçların azaltılması örnek verilmektedir.

c. Kulüp malları, bu tür mallarda ise tüketimde rekabet yoktur ancak faydadan dişlama özelliği mevcuttur. Nitekim bu mallar belirli kulüplere kayıt olunduktan sonra tam kamusal mal hüviyeti taşımaya başlamaktadır. Kulüp mallarında alınan kayıt ücretleri (gönüllüdür) tam kamusal mallara nazaran kaynak tahsisinde adaletin daha etkin sağlanmasına olanak tanımaktadır. Ayrıca üye sayısının artması kalabalıklaşma maliyetinin ortaya çıkmasına ve dışarıda bırakma durumunun gerçekleşmesine neden olmaktadır.

d. Bağlı ürünler, tek sunumda birden fazla ürünün üretilmesini kapsamaktadır. Yani bir yandan ülke sınırları içerisinde fayda sağlarken diğer yandan küresel manada birtakım yararlar meydana getirmektedir. Bu ürünlere örnek vermek gerekirse, diş yardım yapılması durumunda, temelde yoksulluğun azaltılması hedeflenirken hem yardımı alan hem de yardımı yapan ülkeye birçok olumlu etkisi söz konusu olmaktadır. Nitekim gerçekleştirilen yardım ile bulaşıcı hastalıkların önlenmesi, barış 
ve güvenliğin sağlanması gibi faydalar hem ülkeye hem de diğer ülkelere önemli faydalar sağlamaktadır. Küresel kamusal malların sektörlere göre dağılımı ise Tablo 1'deki gibidir.

Tablo 1: Küresel Kamusal Malların Sektörlere Göre Sınıflandırılması

\begin{tabular}{|c|c|c|c|}
\hline \multirow{2}{*}{$\begin{array}{c}\text { Kamusal } \\
\text { Mal }\end{array}$} & \multirow{2}{*}{ Çekirdek Aktivite } & \multicolumn{2}{|c|}{ Tamamlayıcı Aktivite } \\
\hline & & Üretim & Tüketim \\
\hline \multirow{2}{*}{ Çevre } & Gaz Emisyonunun Azaltılması & Araştırma & Yoksulluğun \\
\hline & Canlıların Korunması & Tarımın Desteklenmesi & Azaltılması \\
\hline \multirow{2}{*}{ Sağlık } & Hastalıklarla Mücadele & Hastalıkların Araştırılması & \multirow{2}{*}{ Sağlik Klinikleri } \\
\hline & Önleyici Sağlık Hizmetleri & Sağlık Hizmetleri & \\
\hline \multirow{2}{*}{ Bilgi } & Araştırma Merkezleri & İnternet Hizmetleri & Küresel Ağlar \\
\hline & Eğitim Hizmetleri & Küresel Eğitim & Okullar \\
\hline \multirow{2}{*}{ Güvenlik } & Çatışmaların Önlenmesi & Barışın Korunması & Yoksulluğun \\
\hline & Suç Oranlarının Düşmesi & BMGK* Asayiş Hizmetleri & Azaltılması \\
\hline \multirow{2}{*}{ Yönetişim } & Küresel Kurumlar & Araştırma & Finansal İstikrar \\
\hline & İyi Devlet & Devlet Gücü & Adalet \\
\hline
\end{tabular}

*Birleşmiş Milletler Güvenlik Konseyi

Kaynak: (Yusufoğlu ve Özpençe, 2015: 20).

Tablo 1'den de anlaşılacağı üzere küresel kamusal mallar sektörlere göre çevre, sağlık, bilgi, güvenlik ve yönetişim olarak ifade edilmektedir. Yapılan sınıflandırma çerçevesinde risk ve zararların azaltılmasını hedefleyen küresel kamusal mallar; çevre, sağlık ve güvenlik olarak ifade edilmektedir. Ayrıca bilgi ve yönetişim noktasındaki kamusal mallar ise kapasite arttırıcı etkiye sahiptir (Yılmaz, 2010: 140).

\section{Küresel Kamusal Mal Olarak Çevre ve Çevresel Kirlilikler}

Küresel kamusal mal olan çevrenin korunması esasında hava, kara ve deniz ortamları ile bitki ve canlıları kapsamaktadır. Çevrenin korunması bütün insanlığa fayda sağladığından bu konuda ortaya çıkacak sorunlar ise bütün dünya insanlarının sorunu haline gelmektedir. Bu noktada hava, kara ve deniz trafiğindeki artışa ek olarak teknoloji, sanayileşme, nükleer silahlar, enerji santralleri ve uzaya atılan füzelerin meydana getirdiği kirlilikler dünyadaki tüm yaşam formlarını etkilemektedir (Arsan, 1992: 417-418).

Çevre sorunlarının yerel ölçekte başladığı ancak daha sonra ulusal hatta küresel olarak ilerlemekte olduğu ve tüm dünyayı etkilediği ifade edilmektedir. Bu konuda verilebilecek dikkate değer bir örnek ise Brezilya'da meydana gelen asit yağmurlarının yağmur ormanlarını tahrip etmesiyle önce Brezilya daha sonra Amerika kıtasının güneyi ve en sonunda da tüm dünyayı etkilemesi olarak ifade edilebilir. Yine karbon gazı tüketiminin artması sonucu küresel ısınmanın artması ve ozon deliğinin büyümesi, tüm insanlığın bu durumdan etkilenmesi manasına gelmektedir (Yalçın, 2009: 289).

Çevresel küresel kamusal malların temini; küresel olarak önemli olan esnekliğin ve yenilenmenin tedariğini sürdürmek için kolektif eyleme bağlı olduğu çevresel sistemlere dayanmaktadır (Kok vd., 2011: 13). Küresel kamusal mal olarak çevrenin oldukça önemli iki 
özelliği bulunmaktadır. Çevrenin bu özellikleri, küresel nitelikte olması ve kamusallık boyutudur. Çevreyi ulusallıktan sıyırıp ona küresel düzeyde önem atfeden küresel kamusal mallar ise bu yönüyle kamu maliyesi içerisinde oldukça güncel bir yaklaşımdır. Çevrenin küresel manadaki değeri, onun küresel kamusal mal çerçevesinde ele alınmasına ve küresel manada işbirliği yapılmasını gerekli kılmaktadır (Yalçın, 2009: 289). Küresel kamusal mal olarak çevre, "nehirlerin ıslahı, atık yönetimi, balıkçılık politikası, enerji araştırmaları, orman politikası, ormanların ıslahı, balıkçılığın ıslahı, çevre politikası, biyosfer koruma, bioçeşitlilik, sit alanlarının korunması, sel ve baskınlardan korunma, çevre eğitimi, su kaynakları politikası ve su kaynaklarının korunması" bileşenlerinden meydana gelmektedir (Başaran, 2007: 92).

Çağımızda sanayi üretimindeki artış doğanın dengesini birçok yönüyle tehdit etmektedir (Bulutoğlu, 2008: 281). Yüzyıllar boyunca farklı yoğunluklarda mevcut olan çevre kirliliği, 19. yüzyıldaki sanayi devriminin ardından iyice belirgin hale gelmeye başlamıştır. Kirlilik; doğa, doğal olmayan bir şekilde kendisine gelen bir elementi nasıl imha edeceğini bilmediği ve/veya korunma gücü yıpratıldığı zaman meydana gelmektedir (CEF, 2018a). Bu süreç bazen birkaç gün bazen de radyoaktif kirleticilerde olduğu gibi binlerce yıl sürebilmektedir. Özellikle hava kirliliği insan sağlı̆̆ının yanı sıra asit yağmuru, ötrifikasyon, pus, yaban hayatı, ozon tabakası, mahsul ve ormanlar ile iklim değişikliği gibi alanları da etkilemektedir (MassDEP, 2016: 2-3);

Çevresel kirliliklerden biri olan hava kirliliği oldukça önemli ve olumsuz etkiler meydana getirmektedir. Dünya Sağlık Örgütü verilerine göre hava kirliliği sonucu dünyada her yıl 500 bini Avrupa'da olmak üzere en az 4 milyon kişinin öldüğü ifade edilmektedir. Nitekim ortaya çıkan hava kirliliğinin önemli sebeplerinden biri fosil yakıt kullanımı olup fosil yakıt kullanımı gerçekleştiren otomobiller ise bu konumda önemli birer bileşendir. Özellikle de dizel araçların insan sağlığına verdiği zararlar (kirletici gaz emisyonunun artmasıyla); akciğer kanseri, üst solunum yolu enfeksiyonları, astım, felç gibi hastalıkları arttırırken; diyabet ve demans gibi hastalıkları da tetiklemektedir. Tüm bunlar durumun ne derece önemli boyutta olduğunun açık bir göstergesidir. Ayrıca Hollanda kökenli bir araştırma şirketine göre dizel araçlar, hava kirliliğinin meydana getirdiği maliyetlerin \%83'ünden sorumlu iken bu oran AB ülkelerinde \%66 ila 92 arasında değişmektedir. Avrupa Kamu Sağlığı Birliği'ne göre, bütün bu hastalıkların AB bütçesine maliyeti 2016 yılı için 66.7 ila 79.8 milyar EUR arasindadır (euronews, 2018).

\section{Elektrikli Taşıtlar}

Elektrikli taşıtlar, benzinli/dizel motor yerine şarj edilebilir pillerde depolanan elektrik enerjisini kullanan, bir veya daha fazla elektrik motoruyla çalışan taşıtlar olarak tanımlanmaktadır (SCC, 2019). Her ne kadar yeni bir teknoloji olarak görünse de elektrikli taşıtların tarihi esasında İçten Yanmalı Motor (İYM)'lu taşıtlarınkinden çok daha eskiye dayanmaktadır. Nitekim Profesör Sibrandus Stratingh tarafından ilk elektrikli taşıt 1835 yılında Hollanda'da geliştirilmiştir. Daha sonra, yani 1890'lı yıllarda Avrupa ve ABD'de, şirketlerin elektrikli taşıt üretimi ve satışı yaptıkları görülmektedir. 1900'lerin başına gelindiğinde ise ABD'deki elektrikli taşıtların sayısının benzinli taşıt sayısını geçtiği belirtilmiştir. Menzil artırma düşüncesi elektrik motoru ve benzinli motoru birleştirme fikrini doğurmuş ve bu sayede ilk hibrit yapı ortaya çıkmıştır. Ancak 1920-1960 yılları arasında meydana gelen birtakım gelişmeler (benzin fiyatlarındaki düşüş, marş motorunun 
bulunması, ABD'deki yolların iyileşmesiyle uzun menzilli taşıt ihtiyacının artması, Henry Ford'un IYYM'li taşıtları seri üretmeye başlaması ve bu sayede taşıt maliyetlerinin düşmesi) elektrikli taşıtların düşüşe geçmesine neden olurken İYM'li taşıtların dünya çapında yükselişe geçmesini sağlamıştır. Bu yükselişle birlikte otomotiv şirketleri İYM taşıtların seri üretimine başlamış ve bu durum 1930'larda elektrikli taşıtların ortadan kalkmasına neden olmuştur. Çevre açısından bakıldığında, bu durum teknoloji tarihinin en büyük hatalarından biri olarak görülmektedir. Nitekim fosil yakıtlardan beslenen IYYM'li taşıtların ortaya çıkardığı çevresel tahribatlar oldukça önemli boyuttadır. 1960 yılına gelindiğinde IYYM'li taşıtların ortaya çıkardığı hava kirliliğini azaltmak ve ABD, İngiltere ve Fransa'da yaşanan petrol krizinin etkilerini gidermek amaciyla yeniden elektrikli taşıtlara dönülmüştür. 1980'li yıllara gelindiğinde hükümetler çevre dostu olan elektrikli taşıtlara ekonomik teşvikler vermeye başlamıştır. 2000'li yıllara yaklaşılırken ilk seri üretim hibrit aracın ortaya çıktığı ve benzin fiyatlarındaki artış ile karbon kirliliği noktasındaki endişelerin artması nedeniyle bu dönemden sonra hibrit modellere olan talebin arttı̆̆ görülmektedir (WEC, 2018: 1; Helmers ve Marx, 2015: 2; Bayram, 2017: 12).

Elektrikli taşıt üreten bazı şirketler tüm taşıt modellerini proaktif olmak ve sadece elektrikle çalışma prensibi üzerine kurmuş olsalar da bazıları hem elektrik hem de gazla çalışan hibrit araçlar sunmaktadır. Elektrikli taşıtlar sadece para kazanma amacına hizmet etmekten ziyade sağlıklı ve istikrarlı bir ortama katkıda bulunmayı da hedeflemektedir (CEF, 2018b). Elektrikli taşıtlar; fosil yakıt kaynaklarının mevcut ihtiyacı karşılamadaki yetersizliği, yakıt maliyetlerinde meydana gelen sürekli artış durumu ve temiz enerji sunması gibi sebeplerle karayolu ulaşımında alternatif olarak kullanılmaktadır (Güven ve Rende, 2017: 83). Elektrikli taşıtların yaygınlaştırılması ile fosil yakıtlardan beslenen İYM'li taşıtların çevresel etkilerinin azaltılması amaçlanmaktadır. Bu nedenle elektrikli taşıtlar piyasası her geçen gün büyümektedir. Ülke bazında elektrikli taşıtların otomobil pazarlarındaki yerini değerlendirmek gerekirse Tablo 2'deki gibidir.

Tablo 2: Ülke Bazında Elektrikli Taşıtların Otomobil Pazarlarındaki Yeri (\%)

\begin{tabular}{ccccccccc}
\hline Ülke & $\mathbf{2 0 0 8}$ & $\mathbf{2 0 0 9}$ & $\mathbf{2 0 1 0}$ & $\mathbf{2 0 1 1}$ & $\mathbf{2 0 1 2}$ & $\mathbf{2 0 1 3}$ & $\mathbf{2 0 1 4}$ & $\mathbf{2 0 1 5}$ \\
\hline ABD & - & - & 0.00 & 0.10 & 0.40 & 0.60 & 0.70 & 0.70 \\
Almanya & - & - & - & 0.10 & 0.10 & 0.20 & 0.40 & 0.70 \\
Çin* & - & - & 0.00 & 0.00 & 0.10 & 0.10 & 0.40 & 1.00 \\
Fransa & - & - & - & 0.10 & 0.30 & 0.50 & 0.70 & 1.20 \\
Hollanda & - & - & - & 0.20 & 1.00 & 2.50 & 3.90 & 9.70 \\
İsveç & - & - & - & 0.10 & 0.30 & 0.50 & 1.40 & 2.40 \\
Japonya & - & 0.00 & 0.10 & 0.40 & 0.50 & 0.60 & 0.70 & 0.60 \\
Kanada & - & - & - & 0.00 & 0.10 & 0.20 & 0.30 & 0.40 \\
Norveç & 0.20 & 0.10 & 0.30 & 1.50 & 3.20 & 5.80 & 13.70 & 23.30 \\
Türkiye & - & - & - & - & - & - & - & - \\
\hline
\end{tabular}

*Çin Halk Cumhuriyeti

Kaynak: (Kemfert, 2016: 67).

Tablo 2'den de anlaşılacağı üzere elektrikli taşıt piyasasının yıllar içinde gelişme eğilimde olduğu ve seçilmiş ülke örneklerindeki otomobil pazarının yıllar itibariyle daha büyük oranlar aldığ1 görülmektedir. Tablo 2'de ifade edilen rakamlar elbette ki oldukça düşük 
oranlardadir. Ancak gelişme trendi oldukça ümit vaat etmektedir. Tablo 2' deki rakamlar değerlendirildiğinde en dikkat çekici ülke örneği hiç kuşkusuz ki Norveç olmuştur. 2010 yılında Norveç otomobil pazarının sadece \%0.30’u elektrikli taşıtlardan oluşuyorken 2015 yılına gelindiğinde bu rakamın \%23.30 seviyesine ulaştığ1 görülmektedir. Nitekim sadece 2015 yılında Norveç'te satılan 151 bin otomobilin 26 bini elektrikli taşıtlardan oluşmuştur. Bu da \%17'lik bir kısma karşılık gelmektedir. Norveç'in yanı sıra bir diğer başarılı ülke uygulaması da Hollanda olmuştur. Hollanda otomobil pazarının 2015 yılı itibariyle \%9.70'i elektrikli taşıtlardan oluşmaktadır. Tablo 2'de oransal karşılaştırma söz konusudur ancak ülkelerin rakamsal olarak elektrikli taşıt piyasalarına bakmakta yerinde olacaktır. Rakamsal büyüklük olarak değerlendirildiğinde ise Çin Halk Cumhuriyeti ilk sırayı almaktadır. Çin Halk Cumhuriyeti'nde otomobil piyasası 20.9 milyon (2015 yılı) iken elektrikli taşıt piyasası 147 binde kalmıştır. Ancak satılan 147 binden fazla elektrikli taşıt bu yönüyle Çin Halk Cumhuriyeti'ni dünyanın en büyük elektrikli otomobil pazarına sahip ülkesi konumuna getirmiştir. Bu nedenle 2020 yılına kadar 12.000 yeni şarj istasyonu kurulması hedeflenmektedir (Accenture, 2016: 2-4). Ayrıca Çin Halk Cumhuriyeti elektrikli taşıtlara oldukça önem vermekte ve birtakım geliştirme programları uygulamaktadır. Çin Halk Cumhuriyeti'nde elektrikli taşıtlar ile ilgili yürütülen birtakım pilot programlar bulunmaktadır. Bu programlar Tablo 3'teki gibidir.

Tablo 3: Çin Halk Cumhuriyeti'nde Elektrikli Taşıtlarla İlgili Yürütülen Pilot Programlar

\begin{tabular}{|c|c|}
\hline Şehir & Model \\
\hline $\begin{array}{l}\text { Pekin } \\
\text { Devlet Liderliği Modeli }\end{array}$ & $\begin{array}{l}\text { Hükümet, tercihli politikalara dayanmakta ve güçlü bir elektrikli taşıt } \\
\text { sanayi üssü oluşturmayı amaçlamaktadır. Önemli endüstri oyuncuları } \\
\text { ile aktif olarak iş birliği yapmaktadır. }\end{array}$ \\
\hline $\begin{array}{l}\text { Şangay } \\
\text { Platform-Led İş } \\
\text { İnovasyon Modeli }\end{array}$ & $\begin{array}{l}\text { Jiading'deki elektrikli taşıt uluslararası tanıtım bölgesi, elektrikli } \\
\text { taşıtların gelişimini destekleyecek bir platform sağlamaktadır. } \\
\text { Planlamacılar, şehir genelinde elektrikli taşıt kiralama işini } \\
\text { yaygınlaştırmayı planlamaktadır. }\end{array}$ \\
\hline $\begin{array}{c}\text { Shenzhen } \\
\text { Kooperatif } \\
\text { Ticarileştirme Modeli }\end{array}$ & $\begin{array}{l}\text { Çok sayıda endüstriyel oyuncu sürece aktif olarak katılmaktadır. } \\
\text { Potevio'nun finansal kiralama modeli, elektrikli taşıtların satın alma } \\
\text { maliyetini düşürmektedir. }\end{array}$ \\
\hline $\begin{array}{c}\text { Hangzou } \\
\text { Esnek Kiralama Modeli }\end{array}$ & $\begin{array}{l}\text { İnsanlar; araba veya elektrikli bataryayı ayrı olarak kiralayabilmektedir. } \\
\text { Hangzhou, pil değiştirmeyi benimseyen ilk şehir olmuştur. }\end{array}$ \\
\hline $\begin{array}{l}\text { Chongqing } \\
\text { Hizlı Şarj Modeli }\end{array}$ & Chongqing hızlı şarjlı pillerini takip eden tek pilot şehirdir. \\
\hline
\end{tabular}

Kaynak: (Marquis, 2013: 55).

Fosil yakıt tüketimini azaltması nedeniyle çevresel kirliliklerin azaltılmasında oldukça önemli etkileri olan elektrikli taşıtların sahip olduğu olumlu etkiler, devletleri bu konuda harekete geçmeye ve özel yatırımcıları bu konuda yatırım yapmaya yöneltmektedir. Bu yönüyle gösterilen çabalar oldukça önemli sonuçlar doğurmuştur. Nitekim 2018 yılı itibariyle 1 milyon dolaylarında olan elektrikli taşıt talebinin 2020 yılında 19 milyon, 2025 yılına gelindiğinde 25 milyon, 2027 yılında 27 milyon olacağ ifade edilmektedir. 2040 yılına gelindiğinde, yoldaki araçların \%34 (bu da yaklaşık 530 milyon elektrikli araca karşılık gelmektedir)'ünün elektrikli olacağı tahmin edilmektedir. Artan elektrikli taşıt filosu sayesinde günlük 8 milyon varil olan fosil yakıt talebi düşmüş olacaktır (Sundaram vd., 2018: 
1; Siemens, 2010: 3; ICA, 2017: 1; Bloomberg, 2017: 3). Elektrikli taşıt piyasasındaki fırsatların farkında olan Volkswagen'de 2030 yılına kadar araç modellerini elektrikli hale getirmek için akü ve elektrikli taşıt teknolojisine 84 milyar Amerikan doları (USD) yatırım yapma hedefindedir (WEF, 2018: 7). Bu tür gelişmeler ise elektrikli taşıtların fiyatlarında düşüş sağlanması anlamına gelmektedir. Nitekim 2030 yılına gelindiğinde elektrikli taşıtların IYYM'li taşıtlara göre \%15'e kadar daha ucuz olacağı öngörülmektedir (Soulopoulos, 2017: 8). $\mathrm{Bu}$ da elektrikli taşıt piyasasının gelişmesine olanak sağlayacaktır. Elektrikli taşıtların yaygınlaşması elbette ki kirliliklerden kaynaklanan zararların giderilmesinde oldukça önemli rol oynamaktadır. Bu sebeple elektrikli taşıtların yaygınlaşması oldukça önemlidir. Ancak elektrikli taşıtlar piyasasını etkileyen birtakım faktörlerin olduğu ifade edilmektedir. Bu durumda, elektrikli taşıtlar piyasasını etkileyen faktörler ise Tablo 4'teki gibidir.

Tablo 4: Elektrikli Taşıt Piyasasını Etkileyen Faktörler

\begin{tabular}{|c|c|c|}
\hline Politik Faktörler & Ekonomik Faktörler & Teknolojik Faktörler \\
\hline $\begin{array}{ll}\text { - } & \text { Parasal Sübvansiyonlar } \\
\text { - } & \text { Satın Alma ile ilgili Parasal } \\
& \text { Sübvansiyonlar } \\
\text { - } & \text { Parasal Olmayan Devlet } \\
& \text { Düzenlemeleri } \\
\text { - } & \text { Sarj Altyapisi }\end{array}$ & $\begin{array}{ll}\text { - } & \text { Otomobil Fiyatı } \\
\text { - } & \text { Yakıt Fiyatı } \\
\text { - } & \text { Potansiyel Alıcıların } \\
& \text { Sayısı }\end{array}$ & $\begin{array}{ll} & \text { Menzil } \\
\text { - } & \text { Şarj Süresi }\end{array}$ \\
\hline
\end{tabular}

Kaynak: (Accenture, 2016: 3).

Elektrikli taşıt piyasasının önündeki engellerin incelendiği çalışmalar değerlendirildiğinde Tablo 4'e benzer sonuçlara ulaşılmaktadır. Hollanda'da 47 bin katılımcı ile yürütülen bir anket çalışması, elektrikli taşıtların karşı karşıya olduğu engelleri şarj süresi, menzil ve yüksek fiyat olarak ifade etmektedir. Buna göre katılımclların (ING, 2017: 5);

a. \%40' 1 bu taşıtların yüksek fiyatlı olması,

b. \%28'i tek şarj ile alınan menzilinin düşük olması,

c. \%20'si şarj süresi ve,

d. \%12'si ise diğer sebeplerin elektrikli taşıtların üzerindeki en önemli engeller olduğunu ifade etmiştir.

ING Ekonomi Departmanı tarafından gerçekleştirilmiş olan araştırmanın yanı sıra Dünya Ekonomik Forumu'nun da elektrikli taşıtlar piyasasını etkileyen faktörler üzerine yayınlamış olduğu bir araştırma mevcuttur. Dünya Ekonomik Forumu'na göre elektrikli taşıtların karşı karşıya olduğu engeller daha da detaylandırılarak aşağıdaki gibi ifade edilmiştir. Bu bağlamda öne sürülen engeller ve yüzdesel karşılıkları (WEF, 2018: 8);

a. Şarj imkânının kısıtlı olması: \%45,

b. Bir şarj ile gidilen mesafenin sınırlı olması: \%39,

c. Aracın maliyetinin yüksek olması: \%28,

d. Bilgi eksikliği: \%13,

e. Kendini ispat etmemiş bir teknoloji olması: \%11,

f. Performans, pratiklik ve görünüm noktasındaki sorunlar: \%10,

g. Sinırlı seçim şansının olması: \%9,

h. Güvenlik kaygıları: \%5 ve,

i. Yeniden satış/artık değer: \%4 şeklinde olmuştur. 


\section{Elektrikli Taşıtların Ortaya Çıkardığı Etkiler}

Çevresel kirlilikler en temelinde yerel eksende, daha geniş bir panoramadan bakıldığında ise ulusal hatta küresel çapta tüm yaşam formlarını etkileyen önemli bir fenomen haline gelmiştir. Çevresel kirliliklerin ortaya çıkışı çok çeşitli olabileceği gibi özellikle sanayileşme ve bunun neticesinde kentlerdeki nüfus artışının doğal bir neticesi olarak ortaya çıkmıştır. Sanayileşme düzeyinin artmış olması ise ulaşım imkânlarını arttırarak seyahat kolaylığı sağlamış ve artan kişisel otomobil kullanımı da teşvik ederek sera gazı emisyonlarını arttırmış ve nihayetinde çevresel kirliliklerin artışına neden olmuştur.

Küresel ısınma ve iklim değişikliğinin ortaya çıkardığı etkilerin azaltılmasında sera gazı emisyonlarını azaltma çalışmaları oldukça önemli yer tutmaktadır. Bu çalışmalar, Dünya İklim Konferansları, Birleşmiş Milletler İklim Değişikliği Çerçeve Sözleşmesi, Kyoto Protokolü ve Kopenhag Uzlaşması çerçevesinde devam etmektedir. Kara yolu ulaşımında kullanılan motorlu taşıtların harcadığı fosil yakıtlardan meydana gelen sera gazı emisyonlarının azaltılması amacıyla taşıtlarda daha düşük emisyon yayan (ileri İYM teknolojileri, alternatif yakıtlar, hibrit ve elektrikli taşıtlar vb.) alternatif tahrik sistemlerinin kullanımı ön plana çıkıştır (OTEP, 2010: 3).

Çin Halk Cumhuriyeti ve Hindistan'da yükselen orta sınıfın varlığı, taşıt talebinin ve yakıt tüketiminin oldukça artmasına neden olmaktadır. Bununla birlikte 2010 yılında 750 milyona kıyasla 2050 yılına gelindiğinde 1.5 milyar taşıtın yollarda olması beklenmektedir. Petrolün sınırlı bir kaynak olduğu dünyada, alternatif bir ulaşım yakıtı kaynağı olan elektrik sadece akıllı bir yatırım kaynağı değil aynı zamanda kaçınılmaz bir durum olarak karşımıza çıkmaktadır (IEDC, 2013: 5). Görüldüğü gibi sera gazı emisyonları oldukça önemli bir sorun teşkil etmektedir. Bu sorun çerçevesinde yerel yetkililerin aşağıdaki önlemleri alarak sera gazı emisyonlarını azaltmaya da yardımcı olabileceği ifade edilmektedir (EEA, 2018);

a. Enerji tasarrufu ve enerji verimliliği programları yoluyla, fosil yakıt emisyonlarının azaltılmasi,

b. Orman yıkımlarının durdurulması,

c. Karbondioksiti atmosfere geri kazandırmak için ağaç dikiminin arttırılması,

d. Çelik, tuğla ve çimento gibi enerji yoğun malzemeler yerine, bina için sürdürülebilir ve yönetilebilir kaynaklardan kereste kullanımının teşvik edilmesi,

e. Kloroflorokarbon içeren ürünlerin kullanımının azaltılması, mümkünse ortadan kaldırılması ve,

f. Ulaşım kaynaklı emisyonları azaltılması şeklindedir.

Yerel yetkililerin alacağı önlemler elbette ki önemlidir. Ancak tüm yerkürede aynı performansın gerçekleşmesi olanağı oldukça sınırlıdır. Ortaya çıkardığı etkilerin yüksek oluşu (fosil yakıt tüketiminin azalması ile) ve geniş coğrafyalarca kullanılması nedeniyle elektrikli taşıtların kirliliklerin çözümünde önemli rol oynayacağı düşünülmektedir. Nitekim taşıtlar, atmosfere fırlatılan, bizi kirlilik ve sera gazı gibi şeylere karşı savunmasız bırakan, yoğun bir karbon emisyonu üretmektedir. Bu durumda yaşadığımız çevreye olumlu katkıda bulunabilmek için elektrikli taşıt kullanımı ileriye doğru oldukça büyük bir adım niteliğindedir (CEF, 2018a).

Farklı kuruluşların elektrikli taşıtlar ile ilgili yapmış olduğu birçok çalışma mevcuttur. Bu bağlamda 3 farklı kuruluşun elektrikli taşıtların verimliliği üzerine gerçekleştirmiş olduğu araştırmaların sonuçlarını karşılaştırmak gerekirse Tablo 5'teki gibidir. 
Tablo 5: Farklı Kuruluşların Elektrikli Taşıtlarla İlgili Elde Ettiği Bulgular

\begin{tabular}{|c|c|c|c|}
\hline Etki Alanı & $\mathrm{ADL}^{*}$ & $\mathrm{UCS}^{*}$ & NBER* \\
\hline $\begin{array}{l}\text { Toplam Sahip } \\
\text { Olma Maliyeti }\end{array}$ & $\begin{array}{l}\text { Elektrikli taşıtlar, İYM'e } \\
\text { göre \%44 daha pahalıdır. }\end{array}$ & - & - \\
\hline $\begin{array}{l}\text { Küresel Isınma } \\
\text { Potansiyeli }\end{array}$ & $\begin{array}{c}\text { Elektrikli taşıtlar, İYM'e } \\
\text { göre \%23 daha az küresel } \\
\text { 1sınma potansiyeline } \\
\text { sahiptir. }\end{array}$ & $\begin{array}{l}\text { Elektrikli taşıtlar, İYM'e } \\
\text { göre } \% 51 \text { daha az } \\
\text { küresel 1sınma } \\
\text { potansiyeline sahiptir. }\end{array}$ & $\begin{array}{l}\text { Elektrikli taşıtlar, İYM'e } \\
\text { göre, \%40 daha az } \\
\text { küresel ısınma } \\
\text { potansiyeline sahiptir. }\end{array}$ \\
\hline $\begin{array}{l}\text { İkincil } \\
\text { Çevresel } \\
\text { Etkiler }\end{array}$ & $\begin{array}{c}\text { Elektrikli taşıtlar, } 3 \text { kat } \\
\text { daha fazla insanı tokside } \\
\text { etme potansiyeline } \\
\text { sahiptir. }\end{array}$ & - & $\begin{array}{c}\text { Elektrikli taşıtlar, yerel } \\
\text { kirleticilerden } 3 \text { kat } \\
\text { daha fazla hasar } \\
\text { almaktadır. }\end{array}$ \\
\hline
\end{tabular}

*ADL: Arthur D Little; UCS: Union of Concerned Scientists; NBER: National Bureau of Economic Research.

Kaynak: (Brannan ve Barder, 2016: 2).

Tablo 5'teki bulgular değerlendirildiğinde, elektrikli taşıtların, küresel 1sınmayı azaltma potansiyelinin \%23 ile \%51 arasında olduğu görülmektedir. Ancak diğer yandan elektrikli taşıtların daha yüksek satın alım maliyetlerinin olduğu, bireyleri tokside etme düzeyinin ve yerel kirleticilerden etkilenme oranının ise daha yüksek olduğu görülmektedir. Birçok çalışma, elektrikli taşıtların (otomobil vb.) türdeşlerine göre daha verimli olduğunu ve İYM'li arabalardan daha az sera gazı ve diğer emisyonları meydana getirdiğini ifade etmektedir. Beklenen performansa dayalı AB çalışması, 2020 yılında bir elektrikli aracın, aynı mesafeye giden bir benzinli aracın tükettiği enerjinin yalnızca üçte ikisini kullanacağını ortaya koymuştur (The Guardian, 2018a; Carley, 2014: 2). Ayrıca elektrikli taşıtlar normal benzinli taşıtlara oranla çok daha düşük yıllık maliyet yaratmaktadır. ABD'de benzinli bir taşıt kullanmanın yıllık maliyeti ortalama olarak 1.117 USD iken elektrikli otomobilin yıllık ortalama maliyeti ise 485 USD' $^{\prime}$ ir (Sivak ve Schoettle, 2018: 6).

ABD için de elektrikli taşıtların ortaya çıkardığı birçok etki söz konusudur. Bu kapsamda elektrikli taşıtların ortaya çıkardığı faydalar; elektrik tüketiminden kaynaklı çevresel faydaların artması, istikrarsız Ortadoğu ülkelerine petrol yönünden bağımlılığın azaltılması ve yakıt alıminın azaltılması durumunda ithal maliyet avantajı ve bakım maliyetlerinin düşmesi olarak ifade edilmektedir (USDE, 2011: 2). Elektrikli taşıtlar fosil yakıt tüketen taşıtlara göre daha düşük işlem maliyetleri ve daha temiz hava sunmaktadır. Bu nedenle ABD'nin Maryland eyaleti bu taşıtları satın alan veya kiralayan işletmeler için birtakım teşvikler sağlamakta, alınan aracın akü kapasitesine göre 2.500 ile 7.500 USD arasında vergi indirimi sağlamaktadır (Maryland, 2018: 8).

Elektrikli taşıtlar, özellikle çevreye duyarlı kaynaklardan üretim gerçekleştiren temiz bir elektrik şebekesi tarafından şarj edildiğinde, küresel ısınma emisyonlarını önemli ölçüde azaltma potansiyeline sahiptir (Nealer vd., 2015: 1). Yani elektrikli taşıtların ortaya çıkardığ 1 etkilerin daha da artması için elektrik üretiminde kullanılan enerji kaynaklarının da yenilenebilir olması oldukça önemlidir. Bu duruma ABD örneğini vermek gerekirse, $A B D^{\prime}$ de ulaşım sektörü toplam enerji tüketiminin \%28'ini meydana getirmektedir. Bu noktada, ABD'de üretilen elektriğin; \%43.5'i kömür, \%22.2'si doğal gaz, \%19.1'i nükleer, \%8.9'u hidroelektrik, \%5.4'ü ise güneş, rüzgâr ve jeotermal, \%0.7'si ise petrol'den üretildiği 
görülmektedir (USDE, 2011: 2; ORNL, 2017: 3). İsveç'te ise elektrik üretiminin \%90'1 hidrolik ve nükleerden karşılanmaktadır (EU, 2012: 32). Elektrik üretiminde en önemli çevre sorunları termik santrallerden özellikle de linyite dayalı santrallerden kaynaklanmaktadır. Çünkü termik santraller yakılan çeşitli fosil yakıtlardan (kömür, fueloil, doğal gaz vb.) elde edilen enerjiyi kullanmaktadır (Ertürk vd., 2006: 57). AB, ABD ve Türkiye'nin elektrik üretiminde kullandıkları yakıt kaynaklarının yüzdesel payını ifade etmek gerekirse Tablo 6' daki gibidir.

Tablo 6: Fosil Yakıt Türlerinin Elektrik Üretimindeki Paylarının Projeksiyonu (\%)

\begin{tabular}{ccccccccccc}
\hline Ülkeler & AB & ABD & TR & AB & ABD & TR & AB & ABD & TR & AB \\
\hline Yillar & $\mathbf{1 9 9 0}$ & $\mathbf{1 9 9 0}$ & $\mathbf{1 9 9 0}$ & $\mathbf{2 0 0 0}$ & $\mathbf{2 0 0 0}$ & $\mathbf{2 0 0 0}$ & $\mathbf{2 0 1 0}$ & $\mathbf{2 0 1 0}$ & $\mathbf{2 0 1 0}$ & $\mathbf{2 0 2 0}$ \\
\hline Kömür & 54.4 & 74.6 & 58.82 & 39.5 & 72.7 & 42.50 & 32.8 & 62.1 & 42.21 & 37.5 \\
Sivı Yakıt & 23.5 & 5.7 & 11.48 & 21.7 & 4.0 & 5.41 & 20.0 & 1.0 & 2.36 & 15.7 \\
Gaz & 17.2 & 16.8 & 29.70 & 32.1 & 20.2 & 52.04 & 39.8 & 33.9 & 55.41 & 39.4 \\
Biyomas/Atık & 4.9 & 2.9 & - & 6.8 & 3.1 & 0.04 & 7.4 & 2.9 & 0.02 & 7.4 \\
\hline Toplam & $\mathbf{1 0 0}$ & $\mathbf{1 0 0}$ & $\mathbf{1 0 0}$ & $\mathbf{1 0 0}$ & $\mathbf{1 0 0}$ & $\mathbf{1 0 0}$ & $\mathbf{1 0 0}$ & $\mathbf{1 0 0}$ & $\mathbf{1 0 0}$ & $\mathbf{1 0 0}$ \\
\hline
\end{tabular}

Kaynak: (Ertürk vd., 2006: 28-29).

Elektrikli taşıtların çevresel performansının geleneksel yakıt kullanan taşıtlardan daha iyi olduğu ifade edilmektedir. Avrupa'da yapılan bir yaşam döngüsü analizi, elektrikli taşıtların, sera gazı yayılımı yoğun bir elektrikle beslendiğinde dahi karbon ayak izinin daha düşük olduğunu göstermektedir. Bu durum, kara yolu taşımacılığı elektrifikasyonunun, Avrupa'nın karbon emisyonunu azaltmadaki rolünü haklı çıkarmakta ve IYYM'li araçların pilli elektrikli taşıtlar ile değiştirilmesinin yararlarını vurgulamaktadır. Avrupa şebekesine daha fazla yenilenebilir elektrik girdiğinde, elektrikli taşıtların iklim etkisi daha da azalacaktır. Aynı şekilde, pil kimyasının teknolojik olarak geliştirilmesi, pilin depolama amacıyla yeniden kullanılması ve elektrikli piller için geri dönüşüm endüstrisinin geliştirilmesi, sürdürülebilirliklerinde iyileşmelere yol açacaktır (Transport \& Environment, 2017: 10). Örneğin, Britanya Kolombiyası ve Quebec gibi ağırlıklı olarak hidroelektrik enerjisine dayanan yerleşim yerlerinde elektrikli taşıtlar sayesinde sera gazı emisyonları benzer büyüklükteki geleneksel bir araca kıyasla \%80 oranında azalmaktadır. Çoğu şehirde elektrikli taşıtlar, yaşam döngüleri boyunca geleneksel taşıtlara göre \%60 ila 80 daha az sera gazı emisyonu üretmektedir. Dünya Doğayı Koruma Vakfı'nın bu konudaki hedefi ise 2050 yılına kadar \%100 yenilenebilir enerjiye ulaşmaktır (WWF, 2014: 14).

Elektrikli taşıtların çevresel maliyetleri; marjinal elektrik üretiminin herhangi bir dış maliyet üretmediği varsayılırsa sıfır olmaktadır. Bu durum ise taşıtların beklendiği gibi en düşük çevresel maliyetlere sahip olmasını ifade etmektedir. IYYM'ler yerel çevresel maliyetlerin yanı sıra gürültü kirliliğine de neden olmaktadır (Carlsson ve Johansson-Stenman, 2003: 19). Elektrikli taşıtlar ise son derece sessiz olduklarından gürültü kirliliğini azaltmaktadır (Magnusson, 2017: 1). Ancak hibrit ve elektrikli taşıtlar sessiz yapısı trafik güvenliğini etkileyebilmektedir. Bu taşıtlarda gürültü olmaması, sesli algı sayesinde kaçınılan kazalardaki tepki süresini yarıya indirmektedir. Yine yayalar ve bisikletliler daha çok işitsel işaretlere göre hareket ettiğinden, sessiz taşıtların yaklaşması, zaman zaman, özellikle de bu taşıtların menzil dişında olduğu durumlarda, fark edilmemelerine neden olmaktadır. ABD ve Japon makamları, diğer yol kullanıcılarını, özellikle de işitme sorunu yaşayan ve görme engelli olanları, çok sessiz araçların potansiyel olarak daha yüksek risklerine karşı korumak 
için tedbirler aramaktadır. Motorlu taşıtlar için asgari gürültü seviyelerinin belirlenmesi önerilmekte, motorlarının çok sessiz olduğu zamanlarda otomobillerin yapay ses çıkarması gerektiği ifade edilmektedir (Verheijen ve Jabben, 2010: 19).

Elektrikli taşıtların ortaya çıkardığı faydalar, birçok ülkeyi bu konuda hareket etmeye yöneltmiştir. Dünyanın en büyük otomobil pazarı olan Çin Halk Cumhuriyeti, fosil yakıt kullanan taşıtların üretimini ve satışını durdurmak amacıyla bir takvim üzerinde çalışmaktadır. Hindistan, 2030 yılına kadar yeni çıkacak olan tüm araçların elektrikli hale getirileceği yönünde niyetini açılamıştır. Britanya ve Fransa, önümüzdeki 20 yıl içinde tüm benzinli ve dizel araçların satışını durduracaklarını açıklamıştır. Elektro- hareketlilik artık kaçınılmaz görünmektedir ancak bu değişimin iş gücü piyasası üzerinde, petrol ekonomisi ve hatta ulusal vergi sistemleri üzerinde derin etkilerinin olması beklenmektedir (WEF, 2019). Elektrikli taşıtların otomotiv ekosistemi üzerindeki etkileri ise Tablo 7 'deki gibidir.

Tablo 7: Elektrikli Taşıtların Otomotiv Ekosistemine Etkileri

Taşıt Üreticileri Üzerindeki Etkisi

- Elektrikli taşıtlar ile ilgili büyük yatırımların yapılması gerekmektedir.

- Ar-Ge faaliyetlerindeki bütçelerin paylarının arttırılması gerekmektedir.

- Birçok yeni tedarik zinciri ortaklığının oluşturulması gerekmektedir.

- Otomotiv endüstrisi, temel yeni teknolojilere doğru ilerleyecektir.

\section{Satıcılar Üzerindeki Etkisi}

- Bayiler hem elektrikli taşıtları hem de konvansiyonel taşıtları satmayı öğrenmelidir.

- Bayiler, elektrikli taşıtları satmak için personellerini çeşitli beceri setleri ile donatmalıdır.

- Otomotiv iş modelinin elektrikli aracın ortaya çıkmasıyla değişmesi beklenmekte ve bu taşıtlar daha az bakım gerektirdiğinden servis operasyonlarında kârlılığın düşmesi beklenmektedir.

\section{Tedarikçiler Üzerindeki Etkisi}

- Otomobil üreticileri elektrikli güç aktarma sistemine geçtikçe, tedarikçiler önemli ölçüde etkilenecektir. Akülere odaklanmak için ayrı bir bölüme sahip olan Bosch gibi uygun girişimlerde bulunan sadece birkaç tedarikçinin hayatta kalacağı düşünülmektedir.

\section{Nihai Tüketiciler Üzerindeki Etkisi}

- Teşvikler ve sübvansiyonlar, gelgiti elektrikli taşıtlar lehine çevirecektir.

- Hızla büyüyen şarj istasyonları ağı, süper şarj tesisleriyle birleştiğinde elektrikli taşıtların son kullanıcı için daha kolay bir şekilde benimsenmesini sağlayacaktır.

- Yenilikçi özelliklerle üstün sürüş deneyimi, müşterilerin elektrikli taşıt sahibi olmaya direnmesini zorlaştıracaktır. Bir elektrikli taşıtı kullandıklarında geri dönmeleri zor olacaktır.

\section{Hükümet Düzenlemeleri Üzerindeki Etkisi}

- Hükümetler, elektrikli taşıtların benimsenmesinin karbon ayak izini azaltabileceğinden elektrik taşıt girişimini ciddiye almaktadır.

- Hükümetler, elektrik taşıtlarının uygun maliyetli hale getirilmesi ve teşvik edilmesi için sübvansiyonlarla ilgili sorunların çözülmesinde kilit bir rol oynayacaktır.

- Hükümetler otoyollarda geçişlerin kaldırılması ve elektrikli taşıtların benimsenmesini teşvik etmek amacıyla öncelikli park noktalarının sağlanması gibi ayrıcalıklar sunmalıdır.

Kaynak: (Sundaram vd., 2018: 3).

Tablo 7'den de anlaşılacağı üzere elektrikli taşıtların otomotiv ekosistemi üzerinde oldukça önemli değişimler oluşturacağı, yeni oluşum ve dönüşümleri zorunlu kılacağ görülmektedir. Bu noktada elektrikli taşıtların otomobil üreticileri üzerindeki etkisine bir 
örnek vermek yerinde olacaktır. Elektrikli taşıtlar barındırdıkları potansiyelleri nedeniyle yatırımcıların da ilgisini çekmektedir. İngiliz elektrikli süpürge üreticisi Dyson'ın CEO'su Jim Rowan, 2020 yılında elektrikli taşıtlarla ilgili yeni planının tamamlanacağını ve elektrikli taşıtların 2021 yılında lansmanının yapılacağını ifade etmiştir. Bu girişim firmanın, hâlihazırda Singapur'daki fabrikasında çalışan 1.100 olan iş̧̧i sayısının, yeni tesis tamamladıktan sonra iki kattan fazla olacağı anlamına gelmektedir. Elektrik taşıt yatırımlarının artması istihdam üzerinden oldukça önemli etkiler doğurmaktadır (The Guardian, 2018b). Elektrikli taşıtların ortaya çıkardığı diğer bazı etkiler ise şöyledir (IEDC, 2013: 5-7);
a. Yeni iş imkânlarının doğmasına olanak sağlar,
b. İthal fosil yakıtlarına olan bağımlılı̆̆ı azaltır ve,
c. Hizmet maliyetlerinin düşmesini sağlar.

Bazı çevrelerce birçok kirliliğin çözümünün yerel ya da ulusal kökene sahip olduğu söylense de aslında yerel hava kirliliği de hükümetlerin dünya çapında ya da bölgesel olarak hava kirliliğiyle başa çıkacak önlemler üzerinde anlaşma sağlaması gereken sınır ötesi bir sorun olarak ifade edilmektedir (EEA, 2018). Süreç içerisinde çevre koruma ile ilgili uluslararası anlamda dünya ülkelerinin işbirliği yaptığı birçok çalışma söz konusu olmuştur. Bu çalışmalar, 1913 Bern Birinci Uluslararası Doğal Görünümü Koruma Konferansı ile başlamıştır. Daha sonraki dönemlerde ise Birleşmiş Milletler Çevre Programı ve Ekonomik İşbirliği ve Kalkınma Teşkilatı'nın Çevre Komitesi ile devam etmiştir. Ayrıca bu konudaki özel bir örgüt olarak da Uluslararası Doğayı ve Doğal Kaynakları Koruma Birliği faaliyetlerini sürdürmektedir (Arsan, 1992: 417). Bu çerçevede sayılan kurumların da elektrikli taşıtların yaygınlaşması sürecine destek vermesi ve teşvik edici politikalar izlemeleri oldukça önemlidir. Elektrikli taşıtların ortaya çıkardığı birçok olumlu etki söz konusudur. Bu etkileri sıralamak gerekirse şöyledir (CEF, 2018b);
a. Fosil yakıtlara ihtiyaç duyulmaması,
b. Yakıt maliyetlerinin düşmesi ile tasarrufların artması,
c. Emisyonun ortaya çıkmaması,
d. Elektrikli taşıtların popülaritesinin sürekli artması,
e. Diğer taşıtlar gibi test prosedürlerine tabi tutulduklarından güvenli sürüş olanağını sunması,
f. Teknolojik gelişmelerle, maliyet ve bakım maliyetlerinin azalması,
g. Elektrikli motorlarla çalıştığından motor bakım maliyetlerinin düşmesi ve,
h. Sessiz oldukları için gürültü kirliliğine engel olmalarıdır.

Çevre kirliliklerini gidermede elektrikli taşıtların benzer birçok avantajı söz konusudur. Ancak her konuda olduğu gibi elektrikli taşıtlarında pozitif yanlarının yanı sıra bazı dezavantajlara da sahip olduğu unutulmamalıdır. Yakın gelecekte elektriğin kara yolu taşımacılığının ana yakıt kaynağı olacağı dikkate alındığında elektrikli taşıtların üretim ve tüketim sorunlarının en kısa sürede çözülmesi gerektiği ortadadır. Teknolojik gelişmelerle birlikte elde edilecek kazanımlar ilerleyen süreçte söz konusu dezavantajların giderilmesine en azından azaltılmasına olanak tanıyacaktır. Bu kapsamda elektrikli taşıtların üretim ve tüketim aşamasında ortaya çıkardığı ileri sürülen dezavantajlar ise şöyledir (CEF, 2018b; Varun ve Kumar, 2012: 67-68; Brannan ve Barder, 2016: 2; WEF, 2018: 8; ING, 2017: 5);

a. Elektrikli yakıt istasyonlarının hala geliştirme aşamasında ve sınırlı olması, 
b. Elektrikli otomobillerin tamamen şarj edilmelerinin yaklaşık 4 ile 6 saat arasında zaman almasi,

c. Pilin türüne ve kullanımına bağlı olarak, neredeyse tüm elektrikli taşıtların pillerinin her 3-10 yılda bir değiştirilmesi gereği,

d. Pillerin pahalı olması,

e. Elektrik enerjisinin ücretsiz olmaması,

f. Akut elektrik kesintisine maruz kalan şehirlerin elektrikli otomobiller için uygun olmamasi,

g. Menzil ve hız gibi konularda sinurlı olması,

h. Trafikteki diğer arabalardan gelen seslerin azalmasının kazalara neden olma ihtimali,

i. Mevcut elektrikli otomobillerin çoğunun küçük ve iki koltuklu olması,

j. Elektrikli taşıtların insanı tokside etme potansiyellerinin daha yüksek olması,

k. Yerel kirleticilerden daha fazla hasar almaları durumu,

1. Güvenlik kaygılarının bulunması,

m. Sınırlı seçim şansının olması,

n. Yeniden satışta artık değerin azalması riski,

o. Kendini ispat etmemiş bir teknoloji olması,

p. Bilgi eksikliğinin varlığı,

q. Performans konusundaki kaygiların varlığı ve,

r. Taşıtların satın alınmasında sağlanan vergisel teşvik ve sübvansiyonların kısıtlı olması şeklinde sıralamak mümkündür.

Elektrikli taşıtların bir diğer dezavantajı ise fiyat noktasında ortaya çıkmaktadır. Bu sorun temelde elektrikli taşıtların bir gün otomobil pazarına tam olarak girip giremeyeceği sorusu açısından önemlidir. Nitekim elektrikli taşıtların ortalama alış fiyatı (45.316 EUR); 2001 yılı bazında Avrupalıların yeni bir araba için ödeyeceği ortalama fiyattan (15.313 EUR) yaklaşık üç katı ve 2009 yılı ABD fiyatının (20.826 EUR) iki katından fazla olduğu görülmektedir (Grünig vd., 2011: 19).

Elektrikli taşıtların önemle dikkate alınması gereken bir diğer dezavantajı da ev veya iş yerlerine kurulacak olan batarya şarj istasyonlarının yatırım maliyetlerinin yüksek olmasıdır. $\mathrm{Bu}$ durum elektrikli taşıtlara erişim ve kullanım olanağını kısıtlamaktadır. Kişisel şarj istasyonu problemini çözmek amacıyla; kamusal alanlara şarj istasyonlarının kurulması, şarj istasyonlarının altyapı hazırlıklarının tamamlanarak şebeke güvenliklerinin sağlanması ve istasyon sayısının artırılması gerekmektedir. Ayrıca elektrikli taşıt temininde yapılacak yasal düzenlemeler, teşvikler, vergi indirimi ve muafiyetler gibi argümanların kullanımı ise elektrikli taşıtlara olan talebin artmasına katkıda bulunacaktır (Kerem, 2014: 12).

\section{Sonuç}

Açıkça bilindiği üzere çevresel kirliliklerin ortaya çıkmasında en önemli etkenlerden biri taşıtların kullandığı fosil yakıtlardır. Bu noktada ulusal düzeyde önlemlerin alınması elbette önemlidir. Ancak bilimsel gerçekler ışığında fosil yakıt kullanımını minimize etmenin önde gelen çözüm yolunun elektrikli taşıt kullanımının yaygınlaştırılmasından geçtiği inkâr edilmez bir gerçektir. Çünkü elektrikli taşıtlar başta çevre kirliliği sorunu olmak üzere birçok noktada yerel, ulusal hatta küresel etkiler yaratmaktadır. Ayrıca taşıt kullanımının yaygın olması da bu taşıtların çevresel kirliliklerin çözümünde önemli rol oynamasına olanak sağlamaktadır. Bu taşıtların ortaya çıkardığı olumlu etkilerin yüksek olması, birçok ülke 
tarafından talep görmesine ve geleceğin elektrikli taşıtlar piyasasında yer almak için üretime geçmelerine sebep olmaktadır.

Her yeni teknolojide olduğu gibi elektrikli taşıtlarda da Ar-Ge, doğrudan ve dolaylı maliyetler, teşvik mekanizmasında aksaklıklar ve benzeri yetersizlikleri söz konusudur. Bu bağlamda elektrik üretiminde kullanılan enerji kaynaklarının daha yüksek düzeyde yenilenebilir enerji kaynaklarına dayanması, elektrikli yakıt istasyonlarının yetersizliği, taşıtların menzil konusunda yaşadığı sorunlar, şarj süresinin uzun olması, kullanılan pillerin yüksek maliyetli olması gibi sorunlarının çözülmesi, pil kimyasının teknolojik olarak geliştirilmesi, pilin depolama amacıyla yeniden kullanılması ve elektrikli piller için geri dönüşüm endüstrisinin geliştirilmesi çevresel kirliliğin indirgenmesi ve sürdürülebilirliği ile uygun teknoloji çizgisinin muhafaza edilmesinde önemli iyileşmelere yol açacaktır. Bu konuda yapılacak gerek çalışma gerekse düzenleme ve uygulamalarda ahenkli bir bütünlüğün sağlanabilmesi için ulusal ve uluslararası arenada iş birliği konusu büyük önem arz etmektedir. Bazı ülkelerde devlet kurumlarının elektrikli taşıtların geliştirilmesi sürecine olumlu düzeyde katkı ve destek verdikleri, bu taşıtların benimsenmesinin karbon ayak izini azaltabileceğinden elektrik taşıt girişimini gereğince ciddiye aldıkları gözlenmektedir.

Günümüzde kıt kaynakların çevreye duyarlı ve yeterince etkin bir şekilde kullanılmamasının yanı sıra çevre kirliliğinin azaltılmasını sağlayacak teknolojilere ayak uydurulamaması önemli bir sorun olarak karşımıza çıkmaktadır. Bununla birlikte olumsuz dişsallıkların çözümü çerçevesinde gelir elde etme amacı daha yoğunluklu olan çevre vergilerinin kullanıldığı da yadsınamaz bir gerçektir. Çevre kirliliği üzerine kamu zoru ile alınan vergilerin çevre sorunlarına her zaman çözüm olamayacağı ve sorunların çözümünde sadece gelir amaçlı cezalandırıcı vergi politikaları uygulamak yerine düzenleyici ve teşvik edici mekanizmalar kurmanın da bir çözüm olacağı ortadadır. Bu gerekçeler ile devlet kurumları tarafından çevreye duyarlı ve çevre kirliliğini indirgeyici teknolojilerin gerek üretim ve gerekse tüketimine teşvik ve destek mekanizmaları ile olanak sağlanarak kaynak kullanımının etkin ve verimli şekilde bu alanlara kaydırılmasına fırsat verilmesi gerekmektedir.

Küresel arenada elektrikli taşıt kullanımının yaygınlaşması için şarj altyapılarının geliştirilmesi, menzil arttırma çalışmalarına hız verilmesi, elektrikli taşıtlara özel park yeri vb. uygulamaların yaygınlaştırılması gibi unsurların yanı sıra elektrikli taşıt alım ve tüketiminin devletçe teşvik ve sübvanse edilmesi ve bu noktada devletin elektrikli taşıt alım ve tüketimine ilişkin sağlayacağı vergisel teşviklerin belirlenmesi, Ar-Ge faaliyetlerinin desteklenmesi, yenilenebilir enerji kaynaklarının optimize edilmesi konusunda çalışmalar yapılması ve yapılacak çalışmalara devletçe destek verilmesi, konuya ilişkin mali kaygıyı tatminden uzak parasal olmayan kamusal düzenlemeler ve mevzuat yapısının oturtulması, devletlerin elektrikli taşıt piyasasında etkinliğini arttırması, elektrikli taşıt konusunda uzmanlaşmış kurum ve girişimleri destekleyen mekanizmaların oluşturulması; elektrikli taşıtların hali hazırda cılız kalmış cazibesini arttırarak pazar hacminin genişlemesine ve çevrenin korunmasına katkı sağlayacaktır.

Küresel kamusal bir mal niteliğindeki çevrenin kaçınılmaz zorunluluk halleri hariç kirletilmesinin önüne geçilmesi ya da en azından makul seviyelere indirgenmesi adına elektrikli taşıtlar; yerel, ulusal, bölgesel hatta küresel düzeyde birçok olumlu etkinin ortaya çıkmasına olanak sağlamaktadır. Bu pozitif etkileri küresel anlamda ifade etmek gerekirse; fosil yakıtların ithalinde istikrarsız Ortadoğu ülkelerine olan bağımlılığın azalması, 1970'li 
yıllarda yaşandığı üzere petrol şokları nedeniyle özellikle de gelişmekte olan ülkelerin sürekli karşı karşıya kaldığı döviz krizi ve darboğazının tekrar etme riskini azaltma rolü üstlenmesi ve ayrıca yenilenebilir enerji kaynaklarının geliştirilmesi ile küresel ısınmanın ortaya çıkardığı doğrudan ve dolaylı olumsuz etkilerin azaltılması olarak ifade etmek mümkündür. Ulus devletler bazında değerlendirildiğinde ise petrol ithalinin azalması ile ortaya çıkacak ithal maliyeti avantajı ve ortaya çıkan ekonomik kaynakların daha verimli alanlara kanalize edilmesine olanak sağlaması, elektrikli taşıtlar endüstrisine giriş ile yeni iş ve istihdam olanaklarının doğması, elektrikli motor bakım maliyetlerinin IYYM'li taşıtlara göre daha düşük düzeyde seyretmesi ve bu durumun kaynak israfını indirgemesi, çevre kirliliğinin azaltılması ile çevre kirliliği kaynaklı hastalıkların nicel ve nitel olumsuz etkilerinin azalması (akciğer kanseri, üst solunum yolu enfeksiyonları, astım, felç, diyabet, demans vs.) ve bu sayede kamusal sağlık harcamalarının da pozitif yönde makul seviyelere indirgenmesi, zehirli gazların azalması ile başta tarımsal üretimde kalite ve pazar artışı ve bu durumun vergi gelirlerini artırıc etkisi, çevresel kirliliklerin azalması ile yeni turizm destinasyonlarının kazanılması ve bu kazanım ile turizm gelirlerinde önemli bir artışın sağlanması söz konusu olacaktır. Tüm bu pozitif yönlü gelişmeler yerelden başlayarak ulusal bölgesel hatta küresel perspektifte yoksulluğu azaltarak refah artışı sağlayacak ve yaşanabilir bir çevrenin sürdürülebilir olmasına önemli derecede katkı sağlayacaktır.

Sonuç olarak elektrikli taşıtların kullanımının yaygınlaştırılması küresel kamusal mal olarak değerlendirilen çevreye ilişkin değişik kademelerde ortaya çıkan bir sorun olan çevre kirliliğinin çözümüne olumlu katkılar sunabileceği gibi gerek toplum sağlı̆̆ında gerek üretim kalitesinde önemli kazanımlara neden olacak gerek kamusal harcamaların indirgenmesinde ve gerekse kamusal gelirlerin artırılmasında etkin bir rol oynayarak kit kaynakların etkin kullanımına da önemli katkı sağlayacaktır.

\section{Kaynakça}

Accenture. (2016). Electric Vehicle Market Attractiveness. Unraveling Challenges and Opportunities, Retrieved from (2019, 1 February) https://www.accenture.com/_acnmedia /PDF-37/accenture-electric-vehicle-market-attractiveness.pdf

Altinay, H. (2013). Global Norms as Global Public Goods. Global Policy Essay, Global Policy.

Arsan, H.Ü. (1992). Kamu Maliyesi Alanında Yeni Bir İnceleme Konusu: Uluslararası Kamusal Mallar. A.Ü. S.B.F. Dergisi, 47(1-2), 403-426.

Aytaç, D. (2018). Küreselleşme, İşsizlik ve Kamu İstihdamı İlişkisi. Maliye Dergisi, OcakHaziran, 131-153.

Başaran, F. (2007). Küresel Bir Kamu Malı Olarak Çevrenin Artan Önemi ve Sayıştay Denetimi. Sayıştay Dergisi, Sayı: 65 (Özel). 89-110.

Bayram, B. (2017). Türkiye Piyasasında Elektrikli Araçlar. International Bodyshop Industry Symposium, Türkiye, Erişim Adresi (2019, 20 Şubat) http://ibisworldwide.com/wpcontent/uploads/2017/03/T\%C3\%BCrkiye-piyasas\%C4\%B1nda-elektrikliara\%C3\%A7lar.pdf

Bloomberg. (2017). Electric Vehicle Outlook 2017. Bloomberg New Energy Finance's Annual Long-Term Forecast of the World's Electric Vehicle Market. Executive Summary, Retrieved 
from (2019, 1 January) https:/data.bloomberglp.com/bnef/sites/14/2017/07/BNEF_EVO_ 2017_ExecutiveSummary.pdf

Brannan, J.W., \& Barder, T.E. (2016). Battery Electric Vehicles vs. Internal Combustion Engine Vehicles. A United States-Based Comprehensive Assessment, Arthur D Little.

Bulutoğlu, K. (2008). Kamu Ekonomisine Giriş. 7. Baskı, Ankara: Maliye ve Hukuk Yayınları.

Carley, D. (2014). The Beginners Guide to Electric Vehicles (EV). Emotive, Retrieved from (2018, 21 December) https://pluginbc.ca/wp/wp-content/uploads/2017/02/EVBeginners Guide_V7.pdf

Carlsson, F., \& Johansson-Stenman, O. (2003). Costs and Benefits of Electric Vehicles - A 2010 Perspective. Journal of Transport Economics and Policy, 37(1), 1-28.

Conserve Energy Future (CEF). (2018a). Environmental Pollution. Retrieved from (2018, 4 December) https://www.conserve-energy-future.com/causes-and-effects-of-environmental -pollution.php

Conserve Energy Future (CEF). (2018b). What is an Electric Car?. Retrieved from (2018, 22 November) https://www.conserve-energy-future.com/advantages-and-disadvantages-ofelectric-ca rs.php

Ertürk, F., Akkoyunlu, A., \& Varınca, K.B. (2006). Enerji Üretimi ve Çevresel Etkileri. Stratejik Rapor No: 14, Türkasya Stratejik Araştırmalar Merkezi-TASAM.

Euronews. (2018). AB'de Dizel Araçların İnsan Sağlığına Maliyeti Yılda 80 Milyar Euro. Erişim Adresi (2018, $30 \mathrm{Kasım})$ https://tr.euronews.com/2018/11/28/ab-de-dizel-araclarininsan-sagligina-maliyeti-yilda-80-milyar-euro

European Environment Ageny (EEA). (2018). Air Pollutants and Global Effects. Retrieved from (2018, 4 December) https://www.eea.europa.eu/publications/2599XXX/page009.html

European Union (EU). (2012). Electric Vehicles in Urban Europe. URBACT.

Grunig, M., Witte, M., Marcellino, D., Jordan, S., \& Essen, H.V. (2011). Impacts of Electric Vehicles - Deliverable 1. An Overview of Electric Vehicles on the Market and in Development. ICF / Ecologic Institute.

Güven, F., \& Rende, H. (2017). Elektrikli Araçların Tasarımında Malzeme Seçiminin Önemi. Engineer and Machinery, 58(689), 81-95.

Held, D., McGrew, A., Goldblatt, D., \& Perraton, J. (2015). Küreselleşme. (Eds. Anthony Giddens), Sosyoloji, 5. Baskı, Ankara: Say Yayınları.

Helmers, E., \& Marx, P. (2012). Electric Cars: Technical Characteristics and Environmental Impacts. Environmental Sciences Europe, 24(14), 1-15.

ING. (2017). Breakthrough of Electric Vehicle Threatens European Car Industry. ING Economics Department.

International Copper Association (ICA). (2017). The Electric Vehicle Market and Copper Demand. IDTechEx.

International Economic Development Council (IEDC). (2013). Creating the Clean Energy Economy - Analysis of the Electric Vehicle Industry. Rockefeller Brothers Fund, Washington. 
Kaul, I., Conceição, P., Goulven, K.L., \& Mendoza, R.U. (2003). Providing Global Public Goods: Managing Globalization. Oxford University Press.

Kazgan, G. (2016). Liberalizmden Neoliberalizme. İstanbul: Remzi Kitabevi.

Kemfert, C. (2016). Promoting Electric Vehicles in Germany via Subsidies - an Efficient Strategy?. DICE Report, December.

Kerem, A. (2014). Elektrikli Araç Teknolojisinin Gelişimi ve Gelecek Beklentileri. Mehmet Akif Ersoy Üniversitesi Fen Bilimleri Enstitüsü Dergisi, 5(1), 1-13.

Kok, M., Brons, J., \& Witmer, M. (2011). A Global Public Goods Perspective on Environment and Poverty Reduction Implications for Dutch Foreign Policy. PBL Netherlands Environmental Assessment Agency.

Magnusson, S. (2017). New Zealand Electric Car Guide. Wellington, Retrieved from (2019, 1 February) http://www.gw.govt.nz/assets/NZ-Electric-Car-Guide-4April2017.pdf

Marquis, C., Zhang, H., \& Zhou, L. (2013). China's Quest to Adopt Electric Vehicles. Stanford Social Innovation Review.

Maryland. (2018). Electric Vehicle Incentives. Retrieved from (2018, 12 December) https://mde.maryland.gov/ma rylandgreen/Documents/EV_dealershipflyer_online.pdf

MassDEP. (2016). Health \& Environmental Effects of Air Pollution. Deparment of Environmental Protection. Commonwealth of Massachusetts.

Matsui, A., \& Morduch, J. (2003). The Strategy of Global Public Goods. Tokyo and New York University. Draft. Retrieved from (2019, 15 January) https://wagner.nyu.edu/files/faculty /publications/2003-11-Aoki-and-Morduch-The-Strategy-of-Global-Public-Goods.pdf

MFA, MEFI. (2002). Global Public Goods. Série Partenariats. MFA-MEFI: Ministry of Foreign Affairs Treasury Directorate - Ministry of the Economy, Finance and Industry.

Nealer, R., Reichmuth, D., \& Anair, D. (2015). Cleaner Cars from Cradle to Grave. Union of Concerned Scientists.

Oak Ridge National Laboratory (ORNL). (2017). 2016 Vehicle Technologies Market Report. Vehicle Technologies Office, Office of Energy Efficiency and Renewable Energy U.S. Department of Energy.

Otomotiv Teknoloji Platformu (OTEP). (2010). Elektrikli Araç Çalışma Grubu Raporu. Erişim Adresi (2019, 20 Şubat) http://www.otep.org.tr/pdf/ELEKTRIKLI-ARAC-CALISMAGRUBU-RAPORU-V.1-09.11.2010.pdf

Savaşan, F. (2017). Kamu Ekonomisi. 7. Baskı, Bursa: Dora Yayıncılık.

Siemens. (2010). The Smart Electric Vehicle Charging Solution. Sitraffic Epos Charging System, Retrieved from (2019, 17 February) https://www.siemens.com/press/pool/de /events/corporate/2010-10-ecartec/epos_ws_en.pdf

Sivak, M., \& Schoettle, B. (2018). Relative Costs of Driving Electric and Gasoline Vehicles in the Individual U.S. States. Report No. SWT-2018-1, The University of Michigan Sustainable Worldwide Transportation, Michigan/USA.

Soulopoulos, N. (2017). When Will Electric Vehicles be Cheaper than Conventional Vehicles?. Bloomberg New Energy Finance. 
Sundaram, V., Muthalan, N., \& Shanmuganathan, K. (2018). Electric Vehicle - Disruptor of the Automotive Ecosystem. View Point, Infosys.

Surrey County Council (SCC). (2019). Thinking of Switching to an Electric Vehicle?. Travel Smart in Surrey.

The Guardian. (2018a). How Green are Electric Cars?. Retrieved from (2018, 12 December) https://www.theguardian.com/football/ng-interactive/2017/dec/25/how-green-are-electriccars

The Guardian. (2018b). Dyson to Build Electric Cars in Singapore - with 2021 Launch Planned. Retrieved from (2018, 12 December) https://www.theguardian.com/technology/ 2018/oct/23/dyson-to-build-electric-cars-in-singapore-with-launch-planned-for-2021

Transport \& Environment. (2017). Electric Vehicle Life Cycle Analysis and Raw Material Availability. Retrieved from (2019, 22 January) https://www.transportenvironment.org /sites/te/files/publications/2017_10_EV_LCA_briefing_final.pdf

United States Department of Energy (USDE). (2011). Benefits of Electric Vehicles: A National Perspective. Charging into the Future!. Electric Vehicle Assoc of DC.

Varun, M., \& Kumar, C. (2012). Problems in Electric Vehicles. International Journal of Applied Research in Mechanical Engineering, 2(1), 67-73.

Verheijen, E., \& Jabben, J. (2010). Effect of Electric Cars on Traffic Noise and Safety. Bilthoven: National Institute for Public Health and the Environment. Report 680300009/2010.

World Economic Forum (WEF). (2018). Electric Vehicles for Smarter Cities: The Future of Energy Mobility. Industry Agenda.

World Economic Forum (WEF). (2019). This is How Electric Cars Will Transform Our Lives. Retrieved from (2019, 20 February) https://www.weforum.org/agenda/2017/10/threeways-electric-vehicles-will-change-our-world

World Energy Council (WEC). (2018). Elektrikli Araçlar. Dünya Enerji Konseyi Türkiye, Yeni Enerji Teknolojileri Çalışma Grubu, YET3.

World Wildlife Fund (WWF). (2014). Transportation rEVolution: Electric Vehicle. Status Update 2014. WWF Canada.

Yalçın, A.Z. (2009). Küresel Çevre Politikalarının Küresel Kamusal Mallar Perspektifinden Değerlendirilmesi. Balıkesir Üniversitesi Sosyal Bilimler Enstitüsü Dergisi, 12(21), 288-309.

Yılmaz, B.E. (2010). Barış ve Güvenlik: Küresel Kamu Malı Olarak Sunumu ve Finansman Mekanizmaları. Anadolu Üniversitesi Sosyal Bilimler Dergisi, 10(1), 137-158.

Yusufoğlu, A., \& Özpençe, Ö. (2015). Küresel Kamusal Malların Sunum ve Finansmanında Ortaya Çıkan Sorunlara Bir Çözüm Önerisi. International Journal of Human Sciences, 12(1), $15-35$. 